\title{
Teaching English Polysemy through Semantic Fields
}

\author{
Hsiu-Ying Liu ${ }^{\mathrm{a},{ }^{*}}$, Cheng-Chung $\mathrm{Kuo}^{\mathrm{b}}$, Yun-Hsuan $\mathrm{Chou}^{\mathrm{c}}$ \\ ${ }^{\mathrm{a}, \mathrm{c}}$ Asia University, No. 500 Liufeng Rd., Wufeng, Taichung, Taiwan \\ ${ }^{\mathrm{b}}$ National Taichung University of Education, No.140, Minsheng Rd., West Dist., Taichung, Taiwan
}

A B S T R A C T

The paper aims to explore the effectiveness of Semantic Field Theory in polysemy teaching by conducting action research. The objective is to cultivate students' concept of metaphor and semantic fields in order to achieve systematic vocabulary retention on the one hand, and to prove that teaching vocabulary through Semantic Field Theory is more effective than traditional methods on the other hand. An experiment is given to sophomores in Asia University, with a pretest, in-class lesson, and posttest. The result shows that the students in the experimental group perform better in the posttest even though their performance in the pretest is worse, which furtherly proves that learning English polysemy through semantic fields is much more effective than traditional teaching methods.
A R T I C L E I N F O

\author{
Paper type: \\ Research Article
}

Article history:

Received: 20 February 2019

Revised: 26 March 2019

Accepted: 4 April 2019

Keywords:

- Semantic field

- Polysemy

- Metaphor

- Voxabulary teaching

\section{Introduction}

Language learning requires the mastery of four skills including listening, speaking, reading and writing, and all of them require vocabulary learning. As for the importance of vocabulary, the linguist David Wilkins states that: "without grammar little can be conveyed, without vocabulary nothing can be conveyed." Basically, people need to use words to express themselves in any language. In Taiwan, vocabulary is regarded as being very important in that many tests use the size of word bank to judge one's English level, showing that word bank is the basic requirement for English proficiency. To teach English vocabulary, many teachers in Taiwan use traditional grammar-translation method by pronouncing a word, spelling it, and translating the word into Chinese. As a result, many students learn vocabulary only by rote in isolation. Such a way fails to keep the words in long-term memory.

How to improve one's vocabulary? Compared with listening and speaking, vocabulary teaching and learning seem to be taken less seriously. Although there are various teaching methods ${ }^{1}$ applicable to vocabulary teaching, it is thought that "memorization" is the only way to enlarge one's word bank. However, memorization is not the only way for vocabulary learning.

It is impossible that a language contains only words with one single meaning since it will give learners a great burden of vocabulary learning. In fact, all languages have polysemy, the capacity for a word to have multiple meanings. The meanings of a polysemous word to some extent, are related so that it is easy to memorize the various meanings if the learner knows the relations of the extended meanings to the original meaning. The study mainly intends to draw teachers' and EFL college students' attention to the connection between semantic

\footnotetext{
* Corresponding Author.

E-mail addresses: violet@asia.edu.tw (H.-Y. Liu), eatonkuo@gmail.com (C.-C. Kuo), wendyjou0217@gmail.com (Y.-H. Chou).

${ }^{1}$ According to Cao (2016), grammatical-translation method, audio-lingual method and communicative teaching method are used to teach vocabulary.

doi: https://doi.org/10.14710/parole.v9i1.1-14
} 
field and polysemy learning. By introducing metaphors and semantic fields to the students, the study attempts to make vocabulary learning easier. In addition, it will be proved that learning vocabulary through semantic fields makes vocabulary become long-term memory.

\section{Theoretical Background}

\subsection{Semantic Field}

The theory of semantic field was first proposed by the Germans and Swiss in the 1920s and 1930s. In particular, Trier (1931), who stressed the connection between semantic fields and semantic change, made a great contribution to the theory of semantic fields. A semantic field is a set of words (or lexemes) related in meaning. Lehrer (1985) defines semantic field more specifically as "a set of lexemes which cover a certain conceptual domain and which bear certain specifiable relations to one another" and provides the conceptual domain of cooking as an example of a simple semantic field. In English, the domain of cooking is divided up into the lexemes boil, bake, fry, roast, etc. Brinton's (2000) definition makes a close relation of semantic field to hyponymy:

"Related to the concept of hyponymy, but more loosely defined, is the notion of a semantic field or domain. A semantic field denotes a segment of reality symbolized by a set of related words. The words in a semantic field share a common semantic property."

Basically, a hyponym refers to a word or phrase whose semantic field is included within that of another word (known as hypernym). In other words, a hyponym is in a type-of relationship with its hypernym. For example, pigeon, crow, eagle and seagull are all hyponyms of bird (hypernym) as well as animal. However, semantic field does not deal with only hyponymy. According to Lehrer (1985), "a basic premise of semantic field theory is that to understand lexical meaning it is necessary to look at sets of semantically related words." Semantically related words include synonyms, antonyms, hyponyms, words with converseness (buy and sell) and words with incompatibility (e.g. cat, dog, cow, horse, pig, etc.)

Semantic Field Theory is always used to study semantic changes. Lehrer (1985) concludes that semantic field theory can contribute to our understanding of semantic change. Basically, semantically related words might undergo parallel semantic change since the change of one word would trigger corresponding transfers among other lexemes. In our opinions, introducing students the rules of semantic change benefits to not only vocabulary learning but also polysemy handling. What is more, learning through the conceptual domains in cognition will lead to long-term memory.

\subsection{Metaphor and Conceptual Metaphor}

Metaphor can yield cognitive insight. It not only appears in songs, poems and literary works but also exists in people's daily life. Lakoff \& Johnson (1980) propose that conceptual metaphors occur in our everyday life; our communication, thinking and action are shaped by it. They believe that humans have a systematic way of thinking, behavior, and expression that belongs to the mode of cognition and thinking. Fang (2014) states that "owing to the existence of metaphor, we can use a small amount of words to describe the countless things and abstract concepts around us, to express our rich feelings." Briefly, conceptual metaphor refers to metaphors existing in human concepts. It creates a relationship between two different concepts where the familiar and concrete concept is used to explain the unfamiliar and abstract one.

\subsubsection{Body-part metaphors}

Human body is well used in language. Through projection, human body is often used as a measure for nonhuman world. As a result, the "foot" of a mountain refers to the bottom of a mountain. According to Tsai (1994), both in English and Chinese, external organs generate metaphorical meanings based on position, shape and function. Liu (1997) states that internal organs can metaphorically refer to a person's disposition or emotion. The findings of both Tsai and Liu tell that the words in the same semantic field would undergo the same semantic change. 


\subsubsection{Animal metaphors}

Under the conceptual metaphor "HUMAN IS ANIMAL", animal metaphors are prevalent in languages. According to Gachugi et al. (2018), animals are so closely related to the human beings that they can provide a rich basis for the conceptualization of human beings and their activities. Lehrer (1985) examines the semantic change of animal metaphors and concludes that "when a member of an animal word set acquires a metaphorical meaning, it facilitates a comparable change in other members of the set."

What are the possible metaphorical meanings of animal words? In the novel Animal Farm, George Orwell has used animal characters to stand for human characters. In both English and Chinese, animal words are frequently used to indicate a person's disposition or personality. Some animals are applied to highlight human's appearance (e.g pig means fat) or behavior (wugui "turtle" means slow). Animal metaphors, as well as bodypart metaphors, display the connection between semantic field and meaning change.

\subsection{Polysemy}

Johnson (1987) defines polysemy as "the phenomenon in which a single word may have many different meanings which are systematically related to each other." Charles Fillmore and Beryl Atkins' definition stipulates three elements: (1) the various senses of a polysemous word have a central origin, (2) the links between these senses form a network, and (3) understanding the 'inner' one contributes to understanding of the 'outer' one.

Usually, the original meaning (also known as prototypical meanings) of a polysemous word comes from our concrete experience. Take head as an example. The original meaning of "head" is "the upper part of the body, including the eyes, nose, mouth and brain". Based on this meaning, "head" derives the meaning "top" (as in at the head of the page) by taking the feature of position and the meaning "intelligence" (as in have a good head for business) by highlighting the function of "head". The derived meanings are closely related to the original one.

Basically, meanings of a word are generated through various ways. As to language change, Traugott \& Dasher (2002) mentioned some mechanisms: reanalysis, analogy, borrowing, metaphor and metonymy, and metaphor is usually recognized as a mechanism of semantic change. It is interesting that words in the same semantic field would undergo the same metaphorization process. For example, animal words refer to human. Therefore, it is necessary to apply semantic field to polysemy teaching.

\section{Literature Review}

\subsection{Problems of English Lexis Teaching in China and Taiwan}

Vocabulary learning and teaching has been a big problem in China and Taiwan for a long time. Chen's (2001) questionnaire survey on vocabulary learning tells that $66 \%$ of the college students in China think that learning vocabulary is a dull and fruitless job. Chen (2003) states that "vocabulary instruction remains the major headache for English teachers and researchers in China". Gao (2010) points out three difficulties that students encounter when learning vocabulary: (1) Students get no strong initiative in vocabulary learning and application, (2) Forgetfulness is a kind of common phenomenon in vocabulary learning, (3) Students learn vocabulary only in one way.

Basically, the findings based on college students in China are quite the same as the phenomenon observed from college students in Taiwan. Since many students think they are forced to memorize English vocabulary, they, without a strong motivation, just do what they are asked to do. Eventually, such learning attitude leads to short-term memory.

As for teaching methods, Cao (2016) mentions that grammatical-translation method, audio-lingual method and communicative teaching method are applicable to vocabulary teaching. In Fang's (2014) opinion, even though traditional English teaching methods have some positive effect on English vocabulary teaching, they are not effective and systematic enough. In Taiwan, many teachers use the traditional grammtical-tranlation method to teach vocabulary. They use a word list to teach students pronunciation and give Chinese translation withough explaining the meaing in English. After that, teachers begin to explain the text and grammar. Learning vocabulary through this way, students can only get what they are given. Wu (2009) points out that students would encounter difficulty when they see words which are not taught and explained by teachers. In other words, 
student have neither active learning nor adaptability. In addition, students always use Chinese structure to learn English. Guo (2005) has pointed out this problem. According to him, since teachers are accustomed to explain words in Chinese, students fail to build up an English brain. This is harmful to students in vocabulary learning in that Chinese and English have quite different structures. Another difficulty is the interpretation of a polyseme. In fact, words can have different meanings in different contexts, so that English vocabulary teaching must not be disassociated from context. Many textbooks published in England and the United States offer contexts for vocabulary learning; however, Taiwanese teachers like to give the Chinese translation without emphasizing the influence of collcation and context to word meaning. In result, students just memorize the Chinese translation of a word and have difficulty in switching among the meanings of a polyseme in different contexts.

Because of weak motivation as well as ineffective teaching method, most students in Taiwan and China learn vocabulary by memorization. Fang (2014) states that memorizing and reciting words by rote, students cannot master the extended meanings. As a result, they fail to use the words appropriately and are always far away from a high level in English learning.

\subsection{Application of conceptual metaphors in English lexis teaching}

Tang (2006) mentions that introducing metaphor theory in a systematic way to students would help students to build up their knowledge of metaphor. By doing this, the traditional rote memory will be changed effectively, and students' study efficiency is also improved greatly. Zheng (2010) states that compounds and derived words can also be taught through metaphor. For example, to teach the word ice-cold, a teacher can map the domain of ICE to the one of COLD. Once when the students know the meanings of ice and cold respectively, they will be able to link the two domains together and successfully get the meaning "as cold as ice." Zheng encourages teachers to explain metaphorical phenomena in vocabulary through word formation. In her opinion, this will help to reduce students' memory difficulties and widen their vocabulary. According to Chen (2010), students can recognize and understand the relationship between words and meanings through conceptual metaphor and enhance their listening, speaking, reading and writing ability.

Fang (2014) advocates the introduction of conceptual metaphors to polysemy teaching. He proposes the steps of polysemy teaching. First, teachers should help students realize the pervasive existence of conceptual metaphors in English. Second, teachers should show students the multiple meanings of a polysemy on the rule of metaphorical thinking. Fang believes that teaching a polyseme in this way will help students get a better understanding of the word and eventually store it in the long-term memory.

\subsection{Application of semantic fields in English lexis teaching}

According to Crow \& Quigley's (1985) study, students can memorize more words by using the semantic field approach rather than traditional approach. The use of semantic field theory in English vocabulary teaching has been supported by many studies. Learners may expand their vocabulary, deepen their understanding of vocabulary and develop an interrelated system of vocabulary through the semantic field theory. Guo (2010) suggests that teachers should not only teach the pronunciation and meanings of a word but also explain its semantic relations, connotation and collocations. By doing this, students can construct semantic fields under various semantic relations.

Applying semantic field theory to vocabulary teaching, Yang \& Min (2008) provided two strategies: category and induction strategy and semantic association strategy. Using the category and induction strategy, teachers can categorize words with the same meaning and similar meaning through the chart or tree diagram. These words can also be analyzed and compared to enhance students' understanding and memory. For example, teachers may give hyponyms of insect to students, including fly, butterfly, dragonfly, firefly, cricket, cockroach, mosquito, moth, cicada, and beetle. Applying Semantic association strategy, teachers guide students to put words in a different semantic field, which will create a different relationship with other words. On the one hand, it is possible to have students develop a long-term memory; on the other hand, it is possible to develop students' imagination and creativity. Take green as an example. This word is synonymous with inexperienced in the field of synonymy. In the field of antonym, green has an opposite meaning to ripe. In the part/whole relationship, green has a relation with red, blue, white, yellow, and purple. They are all included in the semantic field of "color." By guiding students to understand, digest, and memorize the words in the corresponding semantic field, Cao (2016) used the semantic field theory in vocabulary teaching in Henan Polytechnic University. The data and result of her experiment is in support of the effectiveness and usefulness of semantic field theory to English 
vocabulary teaching. Most students are satisfied with the application of semantic field in vocabulary and believe the teaching method could improve their reading ability, basic knowledge, writing ability and their ability of vocabulary acquisition.

The disadvantage of the traditional approach is that students can only remember words during a short period of time. In contrast to the traditional approach, the semantic field approach would perform well on long-term tests of passive vocabulary retention. Hence, the semantic field is an effective teaching approach for helping students learn vocabulary. The previous studies mentioned apply semantic field theory to teach only literal meaning of a word. This study will apply semantic field theory to the English polysemy teaching.

\section{Action Research}

\subsection{Subjects}

63 non-English majors in Asia University, Taiwan are selected to participate in this study for the qualitative observation. The students have all been evaluated by the language center of Asia University already and are required to attend the low intermediate level of English Reading and Writing class. The participants in the research are divided into two groups: experimental group (Class A) and control group (Class B). There were 24 participants in the experimental group (Class A) and 39 participants in the control group (Class B).

\subsection{Instruments}

The instrument in this study is a self-designed English-Chinese translation exercise. The sentences to be translated all contain polysemous words. The main aim is to see how well students can master polysemy and how semantic field can help students to learn metaphorical meanings of a polysemy. The chosen polysemous words belong to four sets of semantic fields: body parts, animals, negative words and internal organs.

The translation exercise consists of 15 sentences; 3 sentences contain body part metaphors, 3 sentences contain animal metaphors, 3 sentences contain internal organ metaphors, 3 sentences contain negative words, and 3 sentences contain just fillers without metaphorical meanings. The order of the questions is random. There are a pretest and a posttest for the translation exercise. The purpose of this design is to see whether semantic field instruction benefits long-term memory. The sentences in the pretest are composed of different words from the sentences in the posttest except the polysemy. Such a design is to test whether the students could understand the meaning of a polysemy in different contexts. The translation exercises for the pretest and posttest are in the Appendix.

\subsection{Procedure}

The study procedure is divided into three parts. First, without knowing the intention of the research, all participants are invited to do the translation exercises (pretest). Second, the lesson class is given two months after the pretest. The posttest is given one month after the lesson. Last, the experimental results are obtained and analyzed. The detailed process of the study is clarified as follows:

Set the direction and scope of the questions and determine the participants

Design the questions for the translation exercise and give the pretest to the students for 20 minutes

Conduct a lesson in two classes for 15-20 minutes.

Class A (Experimental group): Teach the vocabulary through metaphors and semantic fields.

Class B (Control group): Explain the original and extended meanings of vocabulary directly.

Give a posttest to the students for 20 minutes.

Evaluate whether the answers are correct or not

Analyze and compare the results of the pretest and posttest between two classes. 


\subsubsection{A lesson for the experimental group (Class A)}

To explain the correct answers of the pretest, the concept of projection is introduced with figures in order to help students do conceptual mapping. In the following, the quotations mark " " includes the sentences uttered in the class.

\subsubsection{Body-Part Metaphors}

"Human body parts contain some metaphors, such as the position metaphor. Our body can be projected to the outside world. Being projected to a mountain, the top of the body - "head" maps to the top of a mountain while the lowest part of the body - foot maps to bottom of a mountain. In English, we can say the foot of a mountain, and in Chinese, shantou (mountain-head) refers to the top of a mountain."

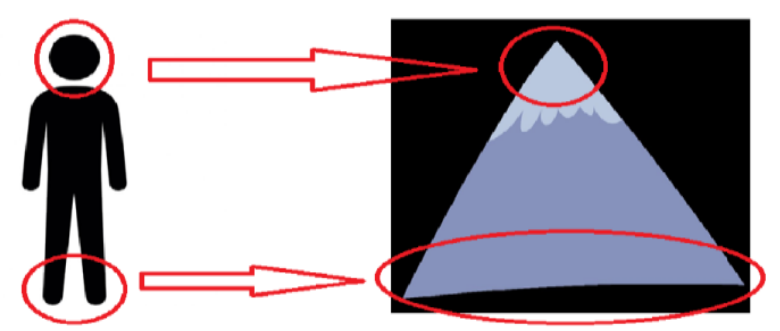

Fig.1: Projection of Body Parts and Outside World

"Being projected to a table, the part of the table used to carry weight is called the leg of the table. The metaphor is based on similarities of the function and shape between the source and target."

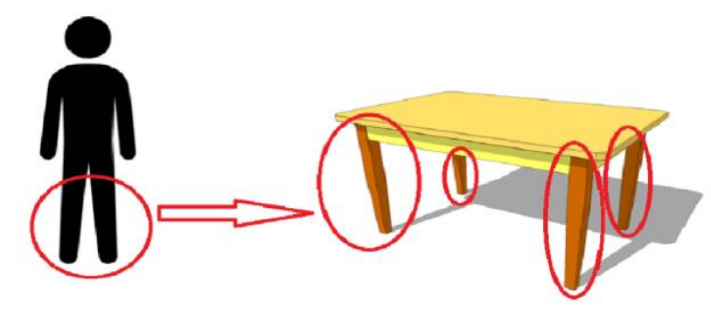

Fig.2: Projection of Legs and the Table

\subsubsection{Animal Metaphors}

As to animal metaphors, students are guided to map the habits or characteristics between animals and humans. By doing this, the concept of HUMANS ARE ANIMALS is taught (Diagram 1).

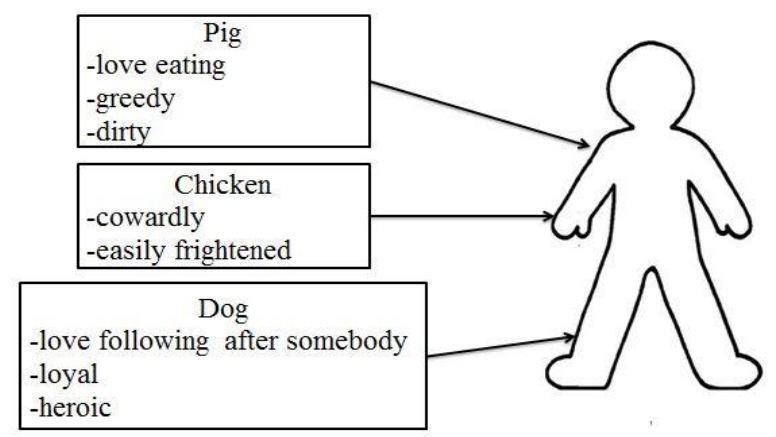

Diagram 1: The Characteristics between Animals and Humans 


\subsubsection{Negative Words}

Liu (2008) has found that words with negative connotations tend to imply "degree." According to her, seven types of words in English could be used as degree adverbs after adding the suffix -ly: DEATH (deadly), DREAD (awfully, terribly), MISERY (miserably, woefully), PAIN (painfully, sorely), SORROW (lamentably, sadly), OUT OF EXPECTATION (surprisingly, astonishingly) and OTHERS (bloody, badly). In class, the derived meanings of words with negative connotations are taught through semantic filed. The linking of semantic field to meaning is explained.

"In English, words with negative connotations tend to generate the meaning of "very", please see Diagram 2".

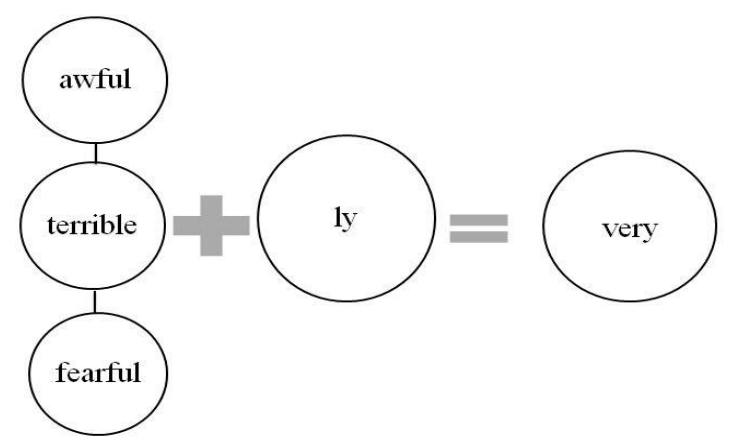

Diagram 2: Words with Negative Connotations

\subsubsection{Internal Organs}

Liu (1997) mentions that words in the same or related field have the same metaphorical meaning, and the internal organs of humans can symbolize human emotions and personality through metaphor.

“In Chinese, 肝腸寸斷gan chang cun duan (broken-hearted) means “very sad.” 肝gan (liver) and腸 chang (guts) are humans' internal organs. They are used to express humans' emotions. There is a similar situation in English, please see Diagram 3".

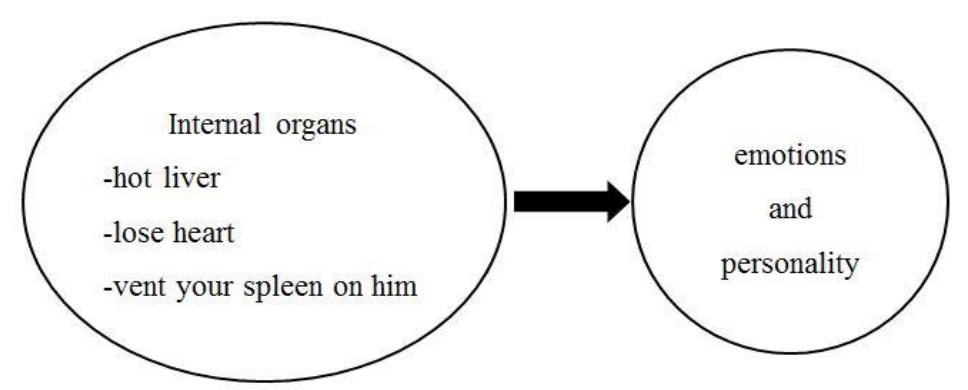

Diagram 3: The Relations between Human Emotions/Personality and Internal Organs

\subsubsection{A lesson for the control group (Class B)}

The original and extended meanings of a word are explained directly to the control group (Class B). The following are slides shown to the students in Class B. In each slide, a) refers to literal meaning while b) shows the metaphorical one. 


\section{身體㣰喻}

- 1.Our house is located in the heart of the city.

我們的房子位於市中心。

a) 心劧

b) 中心

- 2.The village is at the foot of the mountain. 村子在山脚下。

a) 腳

b) 山脸

- 3.The cat clawed at the leg of the table. 猫用爪子抓桌䐥。

a) 腿

b) 槕腳

Slide 1: The Answers of Body Part Metaphors

\section{動物隱喻}

- 1.Whenever I go, my little brother dogs my footsteps. 無論我上哪去, 我的弟弟總是尾隨著我。

a) 狗

b) 尾随

- 2.The doctor told him not to pig himself anymore, or he would suffer from obesity.

醫生告誡他不要再食吃了, 否則他將會患上肥胖症。

a) 㨋

b) 苓吃

- 3.All the boys ran to put out the fire, but Allan chickened out. 男孩都跑去救火, 艾偷卻退縮了。

a) 䌖

b) 退縮

Slide 2: The Answers of Animal Metaphors

\section{程度副詞}

- 1.It is awfully cold here. Let's turn on the heater.

這裡很冷, 我們把暖器打開吧。

- 2.The house was terribly small, Jessie realized quite suddenly.

潔西突然覺得這幢房子非常的窄小。

- 3.Her cheeks burned, she was fearfully thirsty.

她面煩绯紅, 非常口渴。

awfully, terribly, fearfully
a) 可怕地
b）很、非常的=very

Slide 3: The Answers of Negative Words 


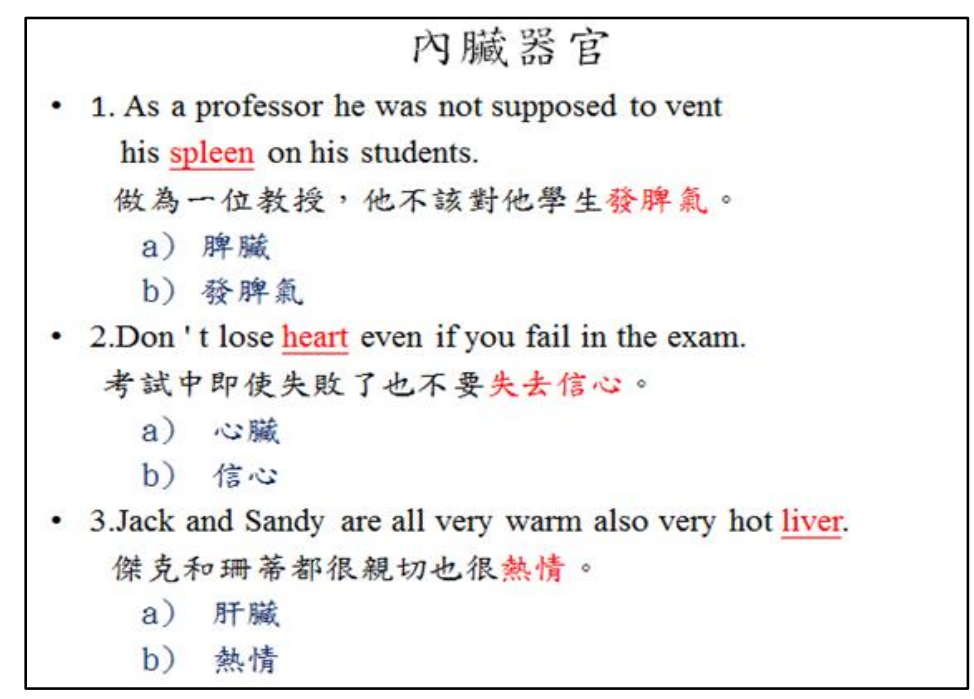

Slide 4: The Answers of Internal Organs

\section{Result}

The following results are obtained by comparing and analyzing the pretest and posttest of the experimental group (Class A) and control group (Class B).

The correctness of the answer is based on whether the lexical semantics are accurate. As can be seen in Table 1 , the proportion of the pretest shows that the performance of the control group (Class B) is obviously better than that of the experimental group (Class A), which indicates that students in Class B are a little better than those in Class A even though both groups are evaluated as the same level.

Table 1. Accuracy of Pretest

\begin{tabular}{llllc}
\hline & Correct & \multicolumn{3}{l}{ Wrong } \\
\cline { 2 - 5 } & $\mathrm{A}$ & $\mathrm{B}$ & $\mathrm{A}$ & $\mathrm{B}$ \\
\hline pre 1 & $87 \%$ & $92 \%$ & $13 \%$ & $8 \%$ \\
pre 2 & $42 \%$ & $67 \%$ & $58 \%$ & $33 \%$ \\
pre 3 & $58 \%$ & $92 \%$ & $42 \%$ & $8 \%$ \\
pre 4 & $0 \%$ & $3 \%$ & $100 \%$ & $97 \%$ \\
pre5 & $29 \%$ & $59 \%$ & $71 \%$ & $41 \%$ \\
pre 6 & $62 \%$ & $79 \%$ & $38 \%$ & $21 \%$ \\
pre 7 & $17 \%$ & $21 \%$ & $83 \%$ & $79 \%$ \\
pre 8 & $75 \%$ & $59 \%$ & $25 \%$ & $41 \%$ \\
pre 9 & $58 \%$ & $69 \%$ & $42 \%$ & $31 \%$ \\
pre 10 & $50 \%$ & $69 \%$ & $50 \%$ & $31 \%$ \\
pre 11 & $46 \%$ & $51 \%$ & $54 \%$ & $49 \%$ \\
pre 12 & $12 \%$ & $23 \%$ & $88 \%$ & $77 \%$ \\
pre 13 & $21 \%$ & $38 \%$ & $79 \%$ & $62 \%$ \\
pre 14 & $21 \%$ & $23 \%$ & $79 \%$ & $77 \%$ \\
pre 15 & $46 \%$ & $67 \%$ & $54 \%$ & $33 \%$ \\
\hline
\end{tabular}

However, being taught through semantic field theory, the results of the posttest in sentences 4,6 and, 12 shows that the growth rate of accuracy of the experimental group (Class $\mathrm{A}$ ) is higher than that of the control group (Class B): $9 \%$ vs. $8 \%, 25 \%$ vs. $0 \%$, and $50 \%$ vs. $41 \%$. This implies that the experimental group (Class A) improve more than the control group (Class B) even though the two groups get a progress after the lesson. 
Table 2. The Growth Rate of Accuracy of Body Part Metaphors

\begin{tabular}{|c|c|c|c|c|c|}
\hline \multirow[t]{2}{*}{ Body Part Metaphors } & & \multicolumn{2}{|l|}{ Correct } & \multicolumn{2}{|c|}{ Wrong } \\
\hline & & $\mathrm{A}$ & B & $\mathrm{A}$ & B \\
\hline Heart of the city & pre 1 & $87 \%$ & $92 \%$ & $13 \%$ & $8 \%$ \\
\hline Heart of Asia & post 4 & & $100 \%$ & $4 \%$ & $0 \%$ \\
\hline Foot of the mountain & pre 6 & $62 \%$ & $79 \%$ & $38 \%$ & $21 \%$ \\
\hline Foot of the hill & post 6 & $87 \%$ & $79 \%$ & $13 \%$ & $21 \%$ \\
\hline Leg of the table & pre 11 & $46 \%$ & $51 \%$ & $54 \%$ & $49 \%$ \\
\hline Leg of the chair & post 12 & $96 \%$ & $92 \%$ & $4 \%$ & $8 \%$ \\
\hline
\end{tabular}

The same phenomenon happens to internal organs (Table 3) as well as animal metaphors (Table 4).

Table 3. The Growth Rate of Accuracy of Internal Organs

\begin{tabular}{|c|c|c|c|c|c|}
\hline \multirow[t]{2}{*}{ Internal Organs } & & \multicolumn{2}{|l|}{ Correct } & \multicolumn{2}{|c|}{ Wrong } \\
\hline & & $\mathrm{A}$ & $\mathrm{B}$ & $\mathrm{A}$ & B \\
\hline Vent someone's spleen & $\begin{array}{l}\text { pre } 4 \\
\text { post } 14\end{array}$ & $\begin{array}{l}0 \% \\
42 \%\end{array}$ & $\begin{array}{l}3 \% \\
26 \%+23\end{array}$ & $\begin{array}{l}100 \% \\
58 \%\end{array}$ & $\begin{array}{l}97 \% \\
74 \%\end{array}$ \\
\hline Lose heart & $\begin{array}{l}\text { pre } 9 \\
\text { post } 9\end{array}$ & $\begin{array}{l}58 \% \\
79 \%\end{array}$ & $\begin{array}{l}69 \% \\
74 \%\end{array}$ & $\begin{array}{l}42 \% \\
21 \%\end{array}$ & $\begin{array}{l}31 \% \\
26 \%\end{array}$ \\
\hline Hot liver & $\begin{array}{l}\text { pre } 14 \\
\text { post } 1\end{array}$ & $\begin{array}{l}21 \% \\
38 \%\end{array}$ & $\begin{array}{l}23 \% \\
28 \%\end{array}$ & $\begin{array}{l}79 \% \\
62 \%\end{array}$ & $\begin{array}{l}77 \% \\
72 \%\end{array}$ \\
\hline
\end{tabular}

Table 4. The Growth Rate of Accuracy of Animal Metaphors

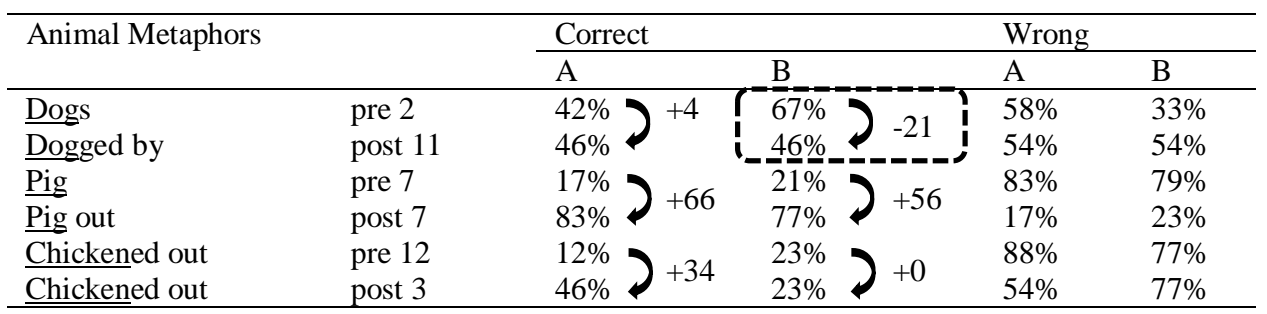

In Table 4, there is a significant improvement in the experimental group (Class A), but the control group (Class B) has a massive decline in proportion. It is surprising that the accuracy of Class B in answering post 11 does not increase but decreases by $21 \%$ while the accuracy of the experimental group (Class A) increases by $4 \%$. In the sentence, $\operatorname{dog}$ is used as a verb and this is not a common usage of the word $\operatorname{dog}$. The decrease of accuracy of Class B implies that the students in the control group cannot deduce meanings through metaphor but only memorize the meaning taught by the teacher.

It seems that negative words are not easy to be handled through semantic field theory. In Table 5, the growth rate of accuracy in Class B appears to be higher than that of Class A. However, it is too early to make a conclusion. As for awfully, the accuracy of Class B decreases by $2 \%$ while that of Class A increases by $25 \%$.

Table 5. The Growth Rate of Accuracy of Negative Words

\begin{tabular}{|c|c|c|c|c|c|c|c|}
\hline \multirow[t]{2}{*}{ Negative words } & & \multicolumn{4}{|l|}{ Correct } & \multicolumn{2}{|c|}{ Wrong } \\
\hline & & $\mathrm{A}$ & & $\mathrm{B}$ & & $\mathrm{A}$ & $\mathrm{B}$ \\
\hline \multirow{2}{*}{ Awfully } & pre 3 & $58 \%$ & & $92 \%$ & & $42 \%$ & $8 \%$ \\
\hline & post 2 & $83 \%$ & +25 & $90 \%$ & -2 & $17 \%$ & $10 \%$ \\
\hline \multirow{2}{*}{$\underline{\text { Terribly }}$} & pre 8 & $75 \%$ & +8 & $59 \%$ & +26 & $25 \%$ & $41 \%$ \\
\hline & post 8 & $83 \%$ & +8 & $85 \%$ & +26 & $17 \%$ & $15 \%$ \\
\hline \multirow{2}{*}{$\underline{\text { Fearfully }}$} & pre 13 & $21 \%$ & +54 & $38 \%$ & +57 & $79 \%$ & $62 \%$ \\
\hline & post 13 & $75 \%$ & & $95 \%$ & $+5 /$ & $25 \%$ & $5 \%$ \\
\hline
\end{tabular}

The results of the experiments display positive effects of both semantic field theory and grammar-translation method on polysemy teaching. But semantic field appears to be more effective in that students given semantic field instruction get a bigger progress. What is more, since the posttest is given one month after the lesson, the 
progress of students in the experiment group tells that semantic field theory and metaphors can lead vocabulary to long-term memory.

\section{Conclusion}

The study investigates the effectiveness of English vocabulary learning for non-English major students who were taught by traditional methods and semantic field theory. The results show that there is a significant difference between the two groups. It reflects that college students' English learning effect can be improved greatly with semantic field instruction. The combination of English vocabulary teaching and semantic field theory is beneficial to vocabulary learning, especially the polysemy. Additionally, conceptual metaphors and semantic fields are effective cognitive tools to deepen the understanding of language and improve students' thinking ability. Moreover, they help students to store vocabulary quickly and efficiently and eventually in longterm memory.

Although the present study has yielded findings that have both theoretical and pedagogical implications, it has some limitations. The experiment only focuses on the learner's reading and writing skills but ignores listening and speaking skills. Additionally, this study is limited by time, participants, and some uncontrollable factors in the experiment. Future studies should increase the number of participants as well as the experiment time.

\section{References}

Brinton, L. J. (2000). The structure of modern English: a linguistic introduction. Illustrated edition. . John Benjamins Publishing Company.

Cao, W. (2016). Vocabulary Teaching Based on Semantic-Field. Journal of Education and Learning, V (3), 64-71.

Chen, H. (2001). Fei Yingyu Zhuanye de Zhongguo Xuesheng Xuexi Yingyu Cihui de Celue: yifen Fenxi Cihui Jiaoxue Celue de Diaocha Baogao非英語專業的中國學生學習英語詞彙的策略：一份分析 詞彙教學策略的調查報告 (Cognitive Metaphor and Its Enlightenment on College Vocabulary Teaching). Journal of Liming Vocational University, II, 50-53.

Chen, L. (2003). A survey of English vocabulary instruction to non-English majors in Chinese common colleges and universities. MA Dissertation, Huazhong Normal University.

Chen, L. (2010). Yinyu Renzhi Dui Daxue Yingyu Cihui Jiaoxue de Qishi 隱喻認知對大學英語詞彙教學的 啟示 (Cognitive Metaphor and Its Enlightenment on College Vocabulary Teaching). Journal of Liming Vocational University, II, 50-53.

Crow, J. \& Quigley, J.R. (1985). A Semantic field approach to passive vocabulary acquisition for reading comprehension. TESOL (19), 497-513.

Fang, X. (2014). Conceptual Metaphor and Vocabulary Teaching in the EFL Context. Open Journal of Modern Linguistics, IV(2). Retrieved from http://file.scirp.org/Html/14-1640239_46793.htm.

Gachugi, F. G., Sikuku, J., \& Kiliku, P. (2018). Animal Metaphor in Gĩkũyũ. Journal of Applied Linguistics and Language Research, $V(2)$.

Gao, Y. (2010). Lun Daxue Yingyu Cihui Jiaoxue 論大學英語詞彙教學 (On College English Vocabulary Teaching). Journal of Xianning College, XXX(1), 79-80.

Guo, Z. (2005). Lun Daxue Yingyu Cihui Jiaoxue 論大學英語詞彙教學 (On the Teaching of College English Vocabulary). Journal of Nanjing Medical University (Social Sciences) 5(3), 262-264.

Johnson, M. (1987). The Body in the Mind: The Bodily Basis of Meaning, Imagination, and Reason. Chicago, IL: University of Chicago Press.

Lakoff, G. \& Johnson, M. (1980). Metaphors We Live by. . Chicago: University of Chicago Press.

Lehrer, A. J. (1985). Historical Semantics: Historical Word-Formation. In J. Fisiak (Ed.), The Influence of Semantic fields on semantic change, 283-296.

Liu, H. (1997). Body-Part Metaphors and Cultural Difference: Chinese and English. M.A. Thesis, National Tsing-Hua University. 
Liu, H. (2008). A Study of the Excessive Construction in Modern Taiwan Mandarin. PH.D. Dissertation, National Tsing-Hua University.

Tang, L. (2006). Cong Yinyu Jiaodu Tan Cihui Jiaoxue 從隱喻角度談詞彙教學 (On Teaching Vocabulary in Terms of Metaphor). Journal of Chongqing University of Science and Technology (Social Sciences Edition), I, 117-120.

Traugott, E. C., \& Dasher, R. B. (2002). Regularity in semantic change. . Cambridge: Cambridge University Press.

Trier, J. (1931). Der deutsche Wortschatz im Sinnbezirk des Verstandes . Dissertation, Heidelberg University, Heidelberg.

Tsai, L. (1994). The Metaphor of Body-parts in Chinese. M. A. Thesis, National Tsing-Hua University.

Wu, D. (2009). Yunyong Goucifa Tigao Daxue Yingyu Cihui Jiaoxue運用構詞法提高大學英語詞彙教學 (To Improve College English Lexical Teaching by English Word-Building). Journal of Hotan Teachers College, XXVIII(3), 138-139.

Yang, P., \& Min, J. (2008). Yuyichang Lilun dui Yingyu Cihui Jiaoxue de Qishi 語義場理論對英語詞彙教 學的啟示 (The Enlightenment of Semantic Field Theory on English Vocabulary Teaching). Teaching monthly (Middle School Edition), II, 12-13.

Zheng, L. (2010). Renzhi Yinyulun yu Gaozhi Yuanxiao Yingyu Jiaoxue Moshi Zhenghe 認知隱喻論與高職 院校英語教學模式整合 (Integration between Cognition Metaphor Theory and English Teaching Mode of Senior High Vocational College). Journal of Language and Literature Studies, III, 173-174. 


\section{Appendix}

\section{Pretest}

Department:

Name:

Student ID:

*Please translate the following sentences into Chinese

1. Our house is located in the heart of the city.

2. Whenever I go, my little brother dogs my footsteps.

3 . It is awfully cold here. Let's turn on the heater.

4. As a professor he was not supposed to vent his spleen on his students.

5 . The hind legs of an animal are usually longer than the forelegs.

6 . The village is at the foot of the mountain.

7. The doctor told him not to pig himself any more, or he would suffer from obesity.

8. The house was terribly small, Jessie realized quite suddenly.

9. Don't lose heart even if you fail in the exam.

10. A number of birds are circling overhead.

11. The cat clawed at the leg of the table.

12. All the boys ran to put out the fire, but Allan chickened out.

13. Her cheeks burned, she was fearfully thirsty.

14. Jack and Sandy are all very warm also very hot liver.

15. Wendy loved Peter's brilliance and generous heart. 
Posttest

Department:

Name:

Student ID:

*Please translate the following sentences into Chinese

1. Jason is falling in love with this hot liver girl.

2. It's all my fault, I'm awfully sorry.

3. Jack was going to make a speech, but he chickened out at the last minute.

4. There is a town in the heart of Asia.

5 . What do you call a part of a leg between your ankle and your knee?

6. They built a house at the foot of the hill.

7. The students like to pig out on junk food. It is unhealthy.

8. Peter speaks Chinese terribly well.

9. Allen failed many times, but he did not lose heart.

10. I received my girlfriend's breaking letter, it really broke my heart.

11. Sam felt very nervous because he was dogged by the police.

12. The cat is sleeping next to the leg of the chair.

13. Susan was fearfully tired. She wants to take a rest.

14. When I get angry, I have to vent my spleen on someone.

15. The birds are eating the fruit. 